\title{
SZEXUÁLIS ERŐSZAKKAL TÁRSULT EMBERÖLÉSEK BUDAPESTEN (2009-2018)
}

\section{HOMICIDES WITH SEXUAL MOTIVATION IN BUDAPEST, HUNGARY (2009-2018)}

\author{
Törő Klára ${ }^{1}$, Kosztya Sándor ${ }^{2}$, Kristóf István ${ }^{3}$, Marcsa Boglárka ${ }^{3}$, Sándor Eszter ${ }^{4}$, \\ Barsi Evelin ${ }^{4}$, Nagy Dóra ${ }^{4}$ \\ ${ }^{1} \mathrm{PhD}$, habilitált egyetemi docens, Semmelweis Egyetem Igazságügyi és Biztositás Orvostani Intézet \\ toro.klara@med.semmelweis-univ.hu \\ 2föorvos, orvos igazgató, Nemzeti Szakértői és Kutató Központ Orvosszakértői Intézet, Budapest \\ ${ }^{3} \mathrm{PhD}$, Nemzeti Szakértői és Kutató Központ Orvosszakértői Intézet \\ 4igazságügyi orvostan szakorvos jelölt, Nemzeti Szakértői és Kutató Központ Orvosszakértői Intézet
}

\begin{abstract}
ÖSSZEFOGLALÁS
A szexuális erőszakkal társult emberölések közé azok az esetek sorolhatóak, melyeknek hátterében szexuális indíték sejthető. A Budapesti Rendőr-főkapitányság adatai alapján 2009-2018 között Budapesten tizennégy ilyen emberölés történt. Számos kutatás támasztja alá, hogy a szexuális motivációjú emberölés igen összetett jelenség, mégis, a legtöbb esetben a halálos kimenetel a szexuális erőszak véletlen következménye. Az emberölések hátterében rendkívül ritkán érhető tetten minden kétséget kizáróan a szexuális indíték, ezért a felderített eseteken túl rejtve maradhatnak olyanok is, melyek kapcsán az előzményi adatok, a helyszíni szemle és a halottvizsgálat során szexuális erőszakra vagy indíttatásra utaló nyom, adat, körülmény nem merült fel. A nemi bűncselekményekkel társult, halállal végződő életellenes bűncselekmények általános jellemzőinek megismerése az etológiai faktorok, oksági kapcsolatok feltárása a megelőzés lehetőségeinek megismeréséhez, az élet mint érték magasabb fokú megbecsüléséhez is hozzájárulhat.
\end{abstract}

\section{ABSTRACT}

Homicides with sexual motivation consist of two main components: homicide and sexual behaviour. According to the data of the Budapest Police Headquarters, 14 homicide cases were classified into this group between 2009 and 2018 in Budapest, Hungary. Numerous studies have confirmed that sex-motivated homicide is a very complex phenomenon, but in most cases, a fatal outcome is an accidental consequence of sexual violence. It can be quite difficult to find clear sexual motivation in the background of homicides, so beyond the discovered cases, there may be a lot more hidden data that remain unknown, because of the anamnestic data, the crime and death scene investigation does not reveal clear sex-related evidences. Getting to know the general characteristics of sexual motivated homicides, the exploration of ethological factors and causal relationships can help develop more effective prevention strategies and can contribute to a higher appreciation of life. 
Kulcsszavak: emberölés, szexuális erőszak, igazságügyi orvostan

Keywords: homicide, sexual assault, forensic medicine

\section{BEVEZETŐ}

Az élet elleni erőszakos büncselekmények jellege, okai és megelőzési lehetőségeik mindig is a közvélemény érdeklődésének középpontjában álltak, hiszen az emberi életet (mint jogtárgyat) veszélyeztető életellenes büncselekményeknek kifejezett a társadalmi veszélyességük. Az életelleni cselekmények megítélése a társadalmi fejlődés különböző szakaszaiban eltérő volt, az emberi élet büntetőjogi védelme a különböző történelmi időszakokban más-más megítélés alá esett. Az életellenes bủncselekmények általánosságban jellemezhetők időbeli, földrajzi előfordulásuk alapján, az elkövetés eszköze, módja tekintetében, a létrejött sérülések jellege és természete alapján. Figyelemre érdemes az elkövető cselekmény utáni magatartása, az életelleni bủncselekmények elkövetőinek és sértettjeinek főbb személyiségjellemzői általános és sajátos ismérvek szerint. Az életellenes büncselekmények okainak megismerése és az azokból levont főbb megállapítások hozzájárulhatnak a felderítések hatékonyságának növeléséhez is. Áttekintésre érdemesnek tartottuk továbbá az emberölésekhez vezető kedvezőtlen makrokörnyezeti ártalmak szerepét, melyek közül a társadalmi elmaradottság, egyes válsághelyzetek előtti, alatti és utáni állapotok szerepe (például gazdasági válság), az agresszió tömegkommunikációban való megjelenése érdemel említést. A mikrokörnyezeti ártalmak vizsgálata, a szocializálódás, elmaradott tudati és kultúrszínvonal, egyes szubkultúrák, speciális helyzetek (szexuális büncselekmények esetében homoszexuális szubkultúra), kedvezőtlen családi nevelési, szociális viszonyok, különböző frusztrációk, alkoholizmus és egyéb függőségek, mentális betegségek, félelmi reakciók vizsgálata, elemzése is célul tüzhető ki a témánk pontos megismeréséhez. Az életellenes büncselekményeket alapvetően konfliktusos, szituatív, nyereségvágyas, leplezéses, szexuális, valamint ideológiai jellegü kategóriákra oszthatjuk fel. Jelen dolgozatban a Budapesten bekövetkezett nemi büncselekményekkel társult, halállal végződő életellenes büncselekmények kerülnek áttekintésre a fenti szempontok figyelembevételével, olyan célból, hogy egyfajta globális áttekintést kaphassunk ezen büncselekmények általános jellemzőiről, elősegítsük egyrészt a kriminológiai, másrészt az igazságügyi orvostani, jogi fogalmak teljesebbé tételét, esetleges továbbfejlesztését. A nemi büncselekményekkel társult, halállal végződő életellenes büncselekmények általános jellemzőinek megismerése, az etológiai faktorok, oksági kapcsolatok feltárása a megelőzés lehetőségeinek megismeréséhez, az élet mint érték magasabb fokú megbecsüléséhez is hozzájárulhat. A nemi büncselekményekkel társult, halállal végződő életellenes büncselekmények megismerésében a külső és belső ténye- 
zők, mind a sértetti (viktimológiai) jellemzők, mind a büncselekményeket generáló szubjektív indítékok kiemelt fontosságúak, elősegítik a jogi megítélést. A szexuális jellegü ölési cselekmények közé sorolható, súlyos pszichés bázison felépülö, az agresszivitás perverziójában, szadizmusban megnyilvánuló szándékos életellenes büncselekmények külön entitást képeznek (Bakóczi, 1984). A jelenlegi hatályos jogi szabályozás (2012. évi C. törvény XV. és XIX. fejezet) külön foglalkozik „Az élet, a testi épség és az egészség elleni büncselekmények” "és „A nemi élet szabadsága és a nemi erkölcs elleni büncselekmények" címszó alatt az emberölés, szexuális kényszerítés és szexuális erőszak tárgykörével.

\section{KÜLFÖLDI STATISZTIKÁK}

A szexuális erőszakkal szövődött gyilkosságok tekintetében nemzetközi szinten is kevés megbízható epidemiológiai adat áll rendelkezésünkre. Az FBI (Federal Bureau of Investigation, Szövetségi Nyomozó Iroda) adatai alapján az USAban 1976-2012 között 709075 személyt tartóztattak le gyilkosság miatt, ebből 5955 esetet $(0,84 \%)$ minősítettek szexuális erőszakkal összefüggésben elkövetett cselekménynek. Az emberölések a halálesetek 15\%-át okozták, melyeknek csupán 1\%-át követik el szexuális indíttatásból. Ez utóbbi arány Kanadában 4\%. Az 1970-es évek közepéhez képest jelentősen csökkentek a szexuális indíttatásból elkövetett emberölések: az utóbbi évtizedben regisztrált esetek száma csaknem két és félszer kisebb, mint az előző két évtizedben.

1976 és 2007 között az ilyen emberölések elkövetőinek átlagéletkora a letartóztatásuk időpontjában 26 év volt (7-76 év). Az elkövetők 89\%-a 18 éven felüli személy. Az áldozatok átlagéletkora 32 év (1-99 év). Az utánkövetett időszak harmadik évtizedére az elkövetők átlagéletkora szignifikáns növekedést mutatott: 25-röl 29 évre ugrott (Myers et al., 2017; Chan-Heide, 2009).

Egy 2016-os tanulmány alapján az említett időszakban férfiak által elkövetett, egy áldozatot követelő esetekben a következő jellemzők voltak megfigyelhetők: az esetek 91,7\%-ában az elkövető nagykorú, míg az áldozat az esetek 13,3\%-ában 12 év alatti, 11,1\%-ában 13 és 17 év közötti, 62,7\%-ában 18 és 59 év közötti, 12,9\%-ában 60 évnél idősebb személy volt (Healey et al., 2016).

Az eszközhasználat tekintetében éllel-heggyel bíró eszköz az esetek 29,3\%-ában került felhasználásra, míg megfojtás, zsinegelés, ütlegelés, taposás, ablakon való kidobás az esetek 42,9\%-ában volt tetten érhetö. Megfigyelhető, hogy a nagy távolságról is alkalmazható eszközök (például lőfegyver) használata háttérbe szorult, és az elkövetés választott eszköze az esetek nagy részében intim közelséget igényelt. Az elkövetők testalkata, az áldozat vulnerabilitásának mértéke, a környezeti tényezők nagyban befolyásolták az eszközválasztást, így lőfegyvert $(4,6 \%)$ főként nők és tinédzser elkövetők használtak. 
Az esetek 81,1\%-ában az áldozat nőnemü volt, 73,4\%-uk 18 éven felüli. 34,6\%-uk korábban nem ismerte az elkövetőt. A cselekmény az esetek 58,9\%-ában külvárosi környezetben történt, gyérebben lakott területeken.

A szexuális indíttatásból elkövetett emberölések elkövetőinek 2\%-ánál a cselekmény ismétlődése figyelhető meg. Az elkövetők ezen csoportjában a családi háttér szerepe még inkább hangsúlyos: a szülők 69\%-a alkoholista volt, míg az egyszeres elkövetőknél ez az arány 45,1\%. A drogabúzus 32,2\%-kal, gyerekkori pszichés abúzus 16,2\%-kal nagyobb arányban volt jelen ezen csoportban (ChanBeauregard, 2016).

Az 1948 és 2010 között Kanadában elkövetett szexuális erőszakkal társult emberölések eseteinek 21,4\%-ában a gyilkosság az áldozat lakásán, 20,6\%-ában nyilvános helyen, 36,3\%-ában erdős területen történt. A test megcsonkítása az esetek 25\%-ára, míg darabolása 6,3\%-ára volt jellemző. A nemi szervek megcsonkítása az esetek 5,4\%-ában volt jelen. Az elkövetök 61,4\%-a külterületen rejtette el a holttestet.

Az FBI viselkedéselemző egységének adatai alapján nekrofil hajlam az amerikai egyesült államokbeli esetek 7,6\%-ában fedezhető fel (Myers et al., 2017), míg a kanadai esetek vonatkozásában ez az arány $10,1 \%$. A tanulmány szerzői szerint ezen jelenségre magyarázatot adhat az elkövető azon vágya, hogy partnere ne tanúsítson ellenállást.

Az elkövetők 80\%-a átlagos testalkatú, 57,2\%-uk családi állapota egyedülálló, míg 15,2\%-uk elvált. 23,6\%-uk mutatta jelét korábban valamilyen szexuális devianciának (leggyakrabban szadizmusnak). 11,2\%-ukat szociális kontaktust kerülő emberként írják le, 38\%-uk büntetett előéletủ. Az elkövetők 8\%-a hajléktalan.

Az áldozatok 89,5\%-a nőnemü volt. 17,7\%-uk prostituáltként dolgozott. 11,1\%uk hajléktalan életmódot élt.

A szexuális aktus tekintetében a behatolás az esetek 46,3\%-ában hüvelyi, 16,3\%-ában anális úton történt, míg az esetek $8 \%$-ában különböző tárgyak révén (Beauregard-Martineau, 2012).

Egy kanadai és franciaországi eseteket összehasonlító tanulmány alapján az elkövetők tekintetében jelentős különbségeket találtak: míg előbbi csoportra az antiszociális személyiség volt jellemző, utóbbi csoportban a szexuális devianciák domináltak (James et al., 2019).

Az erőszakos szexuális büncselekményekkel társult emberölések vonatkozásában nem készült átfogó európai statisztika. Az Eurostat által készített felmérések azt tükrözik, hogy 2013 és 2016 között egyenletesen, 26\%-kal nőtt az erőszakos szexuális büncselekmények száma. Ezen bủncselekmények előfordulási gyakorisága 2016-ban 100000 lakosra vetítve tagállamonként 5 és 190 között változott. Ezeket a különbségeket valószínüleg befolyásolja, hogy az egyes országokban eltér, hogy mit tekintenek büncselekménynek, illetve különbözik a bejelentett incidensek aránya is (URL1). 


\section{FELDOLGOZOTT ESETEINK (2009-2018)}

A Budapesti Rendőr-főkapitányság Nyomozó Főosztályának Életvédelmi Alosztálya által rendelkezésünkre bocsátott adatok alapján, Budapesten, 2009 és 2018 között elkövetett emberölések közül tizennégy esetben fedezhető fel szexuális tartalmú indíték. Megjegyzendő, hogy a szexuális erőszak vagy szexuális tartalmú indíték az emberölések nyomozása során igen ritkán érhető tetten kétséget kizáróan.

A vizsgált időszakban jellemzően egy-három ügy fordult elő évente, a 2014-es, 2017-es, 2018-as évek kivételével, ekkor ugyanis egyetlen esetet sem regisztráltak. Az esetek évszak szerinti megoszlása őszi csúcsot mutat, ekkor hét, a tavaszi, valamint a nyári hónapokban három-három, a téli hónapokban egy eset fordult elö.

Tizenegy alkalommal férfi volt az elkövető, az áldozatok közt hat nő és öt férfi volt, két esetben az elkövető nö, az áldozat férfi, illetve egy esetben csoportos erőszak történt, az áldozat férfi, az elkövetök közt két férfi és egy nő volt.

Egy esetben történt vaginális, egy esetben anális és vaginális behatolás kombinációja, illetve két további esetben különböző tárgyak testnyílásokba való bevezetése említhető.

Három esetben az áldozat aktuálisan, egy esetben korábban élettársi viszonyban élt az elkövetővel, hat esetben az áldozat és az elkövető ismerősi viszonyban állt egymással, míg négy esetben alkalmi kapcsolat valószínüsíthető. Az áldozatok közül három prostituált - két nőnemü, egy hímnemü -, az elkövető pedig mindhárom esetben kuncsaft volt.

A büncselekmény minősítése: három esetben különös kegyetlenséggel elkövetett emberölés, négy esetben emberölés, egy esetben védekezésre képtelen személy sérelmére elkövetett emberölés, két esetben aljas indokból vagy célból elkövetett emberölés, egy esetben halált okozó testi sértés, valamint egy esetben gondatlanságból elkövetett emberölés büntette miatt indult nyomozás. A fentiekhez két esetben szexuális erőszak, két esetben kifosztás büntette társult.

A cselekmény helyszíne két esetben a felek közös lakása, öt esetben az áldozat, valamint egy esetben az elkövető lakása, egy esetben elhagyatott épület, három esetben bokros-erdős terület, illetve egy esetben autó csomagtere.

Az elkövetés eszköze hét incidens során éllel-heggyel bíró eszköz - kés, balta, fejsze -, a szúrások és vágások föként a fej-nyaki és a hasi régiót érték. A fennmaradó esetekben tompa tárggyal való ütlegelésről, illetve testi erővel elkövetett emberölésekröl beszélhetünk: a légzőnyílások befedése, fojtogatás, megtaposás, valamint zsinegelés révén, továbbá az elkövető három esetben kombinált módszert alkalmazott. Az éles-hegyes eszközök használata túlnyomórészt azokra az esetekre volt jellemző, melyekben az elkövető is, az áldozat is férfi volt. 
Az áldozat megkötözésére, védekezésképtelenné tételére három esetben került sor, ebből egy alkalommal a sértett beleegyezésével. Egy esetben az elkövető az áldozat - önszántából elfogyasztott - alkohol és nyugtatószerek hatására való érdemi védekezésre képtelenné válását használta ki a cselekmény végrehajtásához.

A cselekményt követően a holttest elrejtésére öt esetben, ezen belül a test darabolására két esetben került sor. A külső nemi szervek eltávolítása egy - hímnemü - áldozat esetében említhető.

A büncselekmény az esetek több mint felében az esti, éjszakai, hajnali órákban történt. Az elkövetők közül három személy tett bejelentést a rendörségen.

Ismert pszichés betegség egy elkövető esetén volt igazolható, aki téveszmékkel jellemzett hasadásos elmebetegségben szenvedett, büncselekménye idején pszichotikus elmeállapotban volt.

\section{IGAZSÁGÜGYI ELMEKÓRTANI VONATKOZÁSOK}

Büntetőjogi szempontból igen fontos a beszámíthatóság kérdése. Az új Btk. (2012. évi C. törvény) a következőképpen rendelkezik a kóros elmeállapotra vonatkozó szabályokról:

„17. § (1) Nem büntethető, aki a büntetendő cselekményt az elmemüködés olyan kóros állapotában követi el, amely képtelenné teszi cselekménye következményeinek a felismerésére, vagy arra, hogy e felismerésnek megfelelöen cselekedjen.”

A szexuális emberölések elkövetői az esetek többségében nem pszichotikusak a cselekményük elkövetésének időpontjában, valamint nem diagnosztizálható náluk egyértelmủ kóros elmeállapot az elmeorvosi vizsgálatok során. Azonban a különböző hangulatzavarok (különösen a depresszió), valamint a kóros szerhasználat (alkoholizmus, kábítószer-függőség) előfordulása igen gyakori. A szexuális erőszaktevőkre általában a szexuális szadizmus jellemző, ahol a nemi izgalmat az áldozat testi és/vagy lelki szenvedése váltja ki, illetve fokozza. A szexuális szadizmus gyakran antiszociális személyiségzavarral társul, ami a cselekmény ismételt elkövetésére is hajlamosít. Több tanulmány is alátámasztja, hogy a szexuális emberölések elkövetőinél az antiszociális mellett narcisztikus személyiségjegyek is megfigyelhetök, holott teljes személyiségzavar sok esetben nem állapítható meg (Karakasi et al., 2017). A labilis személyiség, empátiára való képtelenség, agreszszív impulzusok, kontrollzavarok gyakran jellemzik a szexuális erőszaktevőket. Az elkövető traumatikus múltja, ha gyermekként bántalmazták, árvaként intézetben nevelkedett, eredményezheti azt, hogy a konfliktuskezelése nem lesz megfelelö, érzelmi sivárság jellemezheti. Gyakoriak az erőszakos cselekmények ott, ahol egy párkapcsolaton belül az egyik fél büntetett elóéletü, hiszen az erőszakos cselekmények a tapasztalat alapján gyakran ismétlődnek, föként családon belüli erőszak esetén, azok gyakorisága és súlyossága is fokozódhat. Nagyobb a kocká- 
zat alkohol- és drogfüggőség, alacsony iskolázottság, munkanélküliség, szegénység esetén. A prostitúcióval foglalkozó személyek különösösen veszélyeztetettek, mivel helyzetükből adódóan kiszolgáltatottak, kevésbé van lehetőségük segítséget kérni (NANE Egyesület-PATENT Egyesület, 2012).

\section{ELHÍRESÜLT ESETEK - KÜLFÖLD}

Franciaországban a 19. század végén élt Joseph Vacher sorozatgyilkos, akire tizenegy gyilkosságot sikerült rábizonyítani. Ezen áldozatok közül négy volt fiú, akikkel fajtalankodott, a többi hét cselekmény nők ellen irányult. Párizsban található lakásában prostituáltakkal történő közösülés folyamán áldozatait bántalmazta, majd a harmadik emeleten található lakásának ablakából ezeket a nőket kidobta (Kenyeres, 1925).

A történelem talán leghíresebb kéjgyilkosa szintén a 19. század végén tevékenykedő londoni Hasfelmetsző Jack. Több esetben meggyilkolta és megcsonkította prostituált áldozatait. A csonkítások részeként áldozatai hasát felvágta, a szerveket szétszaggatta, a külső nemi szerveket megcsonkította, esetenként magával vitte áldozatai egy-egy testrészét (Kenyeres, 1925).

Az Egyesült Államokban 1973 és 1978 között Theodore Bundy több államban legalább harminc nőt erőszakolt és ölt meg. Áldozatait agyonverte, megfojtotta, esetenként megcsonkította vagy elásta őket (U.S. Department of Justice-Federal Bureau of Investigation, 1992).

\section{ELHÍRESÜLT ESETEK - MAGYARORSZÁG}

Kovács Péter, a martfüi rém

1957. július 23-án Tiszaföldvár és Martfü között a Cseszárokban megtalálták egy megfojtott nő holttestét, akinek a ruháit letépték. Öt év múlva 1962. március 5-én Tiszaföldvárról eltünt egy húszéves nő, akinek a holttestét két hónap múlva a Tiszában találták meg, halála fulladás következtében állt be. 1963. november 14-én a homoki vasútállomásnál, a sínek mellett egy újabb női áldozatot találtak, akinek szintén leszaggatták a ruháit. A nő agya és koponyája sérült. Pár hónappal később Tiszaföldváron egy nőt támadás ért, azonban sikerült elmenekülnie. 1965 tavaszán a Tiszából újabb meztelen női holttest került elö, a halált ebben az esetben is fulladás okozta. 1967. június 19-én egy tiszaföldvári nő az esti cipőgyári müszak után tủnt el, később a Körösben, Öcsödnél találták meg meztelen, megcsonkított holttestét. Az öcsödi hídnál üvegszilánkokat és vért találtak. A nyomozás során kiderült, hogy gépkocsikban található ilyen típusú üveg, mellyel sikerült leleplezni a tettest. 
Kovács Péter teherutóval a cipőgyár kapujában nekiment egy láncnak, a lánc betörte a teherautó üvegét, és ezeket az üvegdarabokat találták meg a helyszínen is. A teherautóban megtalálták az áldozat vérét is (Majnár, 1968).

Jancsó Ladányi Piroska

Törökszentmiklóson 1953. október 13. és 1954. augusztus 14. között eltünt öt tizenhárom és tizenhét év közötti lány, akiknek holttestét egy parasztház udvarán lévő kútban találták meg a hatóságok. Az elkövető a parasztházban élő húszéves Jancsó Ladányi Piroska volt, aki beismerő vallomása szerint előbb megfojtotta a lányokat, majd szexuális kapcsolatot létesített áldozataival, akiket végül a kútba dobott (Legát, 2012a, 2012b).

A fentebb ismertetett magyar és külföldi esetekben sorozatgyilkosok követték el a kéjgyilkosságokat. Áldozataikkal haláluk előtt és/vagy után szexuális kapcsolatot létesítettek. Az áldozatok halálát legtöbbször fojtogatás és a fejet ért ütések okozták. A tettesek igyekeztek megszabadulni áldozataiktól, akiket feldaraboltak, elástak, vízbe dobtak. A sértettek nagy része tizenéves lány vagy fiatal nő volt. A gyilkosságok egyik oka, hogy az erőszaktevőnek szexuális izgalmat, kielégülést jelentett az áldozat életének kioltása, az esetek többi részében a gyilkosságot a tettes azért követte el, hogy az erőszaknak ne maradjon tanúja.

\section{KONZEKVENCIÁK}

Az Eurostat felmérései alapján az Európai Unióban az erőszakos szexuális cselekmények száma növekedést mutatott az utóbbi években. A tagállamok tekintetében a bejelentett büncselekmények száma nagy variabilitást mutat, melyre magyarázatot adhat a bejelentett incidensek arányának megoszlása, illetve az egyes tagállamokban egymástól eltérő büntetőjogi szabályozás is. Az FBI 1976-2012 közti időszakot felölelő statisztikai adatai alapján az Amerikai Egyesült Államokban a halálesetek 15\%-a emberölés következménye, míg a gyilkosságok 1\%-át szexuális indíttatásból követték el. A Budapesti Rendőr-fökapitányság adatai alapján 2009-2018 közt budapesti viszonylatban tizennégy olyan emberölés történt, melynek hátterében szexuális indíték sejthető. Számos kutatás támasztja alá, hogy a szexuális motivációjú emberölés összetett jelenség, és bár sok bizonyíték van arra, hogy egyes elkövetök az egyéni pszichopatológiájuk (például szexuális szadizmus) vagy a túlzott agresszió miatt ölnek, mégis, a legtöbb esetben a halálos kimenetel a szexuális erőszak véletlen következménye (Healey et al., 2016). Fontos megjegyezni, hogy mivel az emberölések hátterében rendkívül ritkán érhető tetten minden kétséget kizáróan a szexu- 
ális indíték, ezért a felderített eseteken túl rejtve maradhatnak olyan esetek is, amelyek kapcsán az előzményi adatok, a helyszíni szemle és a halottvizsgálat során szexuális erőszakra vagy indíttatásra utaló nyom, adat, körülmény nem merült fel. Ennek értelmében az esetszám nem lehet reprezentatív. Több nemzetközi szervezet, köztük az ENSZ egészségügyi szervezete, a WHO, az Európa Tanács (Isztambuli egyezmény), is fontosnak tartja az összes illetékes állami szerv és szolgálat bevonását annak érdekében, hogy jogi normák létrehozásával lépjenek fel az erőszak ellen, valamint hangsúlyt fektessenek az áldozatok védelmére és az elkövetőkkel szembeni büntetőeljárásra. A szexuális bántalmazás elleni törvények megfelelő védelmet kell, hogy biztosítsanak minden áldozatnak, sürgetik megfelelő védö- és támogató szolgáltatások kialakítását. Igen fontos az áldozatokkal dolgozó szakemberek hatékonyabb képzése, valamint az erőszak különböző formáinak és azok traumatizáló jellegének tudatosítása, ezáltal azoknak az attitűdöknek, nemi szerepeknek és sztereotípiáknak a megváltoztatása, amelyek az erőszakot elfogadhatóvá teszik. A megelőzésnek fontos lépése lenne az emberkereskedelem és a szexuális kizsákmányolás, prostitúció leküzdése, valamint megelőző és rehabilitációs intézkedések meghozatala (Az Európa Tanács Egyezménye a nők elleni és a családon belüli erőszak megelőzéséről és felszámolásáról, 2011).

\section{KÖSZÖNETNYILVÁNÍTÁS}

Szeretnénk köszönetet mondani Gál Sándor c. r. alezredesnek, a BRFK Nyomozó Főosztály Életvédelmi Osztály vezetőjének, amiért rendelkezésünkre bocsátotta a felhasznált emberölési esetek anyagait.

\section{IRODALOM}

Bakóczi A. (1984): Az emberölés. Budapest: Közgazdasági és Jogi Könyvkiadó

Beauregard, E. - Martineau, M. (2012): A Descriptive Study of Sexual Homicide in Canada: Implications for Police Investigation. International Journal of Offender Therapy and Comparative Criminology, 57, 12, 1454-1476. DOI: 10.1177/0306624X12456682, https://www.researchgate. net/publication/230632153_A_Descriptive_Study_of_Sexual_Homicide_in_Canada_Implications for Police Investigation

Chan, H. C. (O.) - Beauregard, E. (2016): Choice of Weapon or Weapon of Choice? Examining the Interactions between Victim Characteristics in Single-victim Male Sexual Homicide Offenders. Journal of Investigative Psychology and Offender Profiling, 13, 1, 70-88. DOI: 10.1002/ jip. 1432

Chan, H. C. (O.) - Heide, K. M. (2009): Sexual Homicide: A Synthesis of the Literature. Trauma, Violence \& Abuse, 10, 1, 31-54. DOI: 10.1177/1524838008326478, https://www.researchgate. net/publication/23571631_Sexual_Homicide_A_Synthesis_of_the_Literature 
Európa Tanács (2011): Az Európa Tanács Egyezménye a nök elleni és a családon belüli eröszak megelözéséröl és felszámolásáról. Council of Europe Convention on Preventing and Combating Violence against Women and Domestic Violence. CETS No. 210, Istanbul, 11.V.2011, https://www.coe.int/en/web/conventions/full-list/-/conventions/treaty/210

Healey, J. - Beauregard, E. - Beech, A. et al. (2016): Is the Sexual Murderer a Unique Type of Offender? A Typology of Violent Sexual Offenders Using Crime Scene Behaviors. Sex Abuse. DOI: 10.1177/1079063214547583, https://bit.ly/2saV1EM

James, J. - Proulx, J. - Vuidard, E. et al. (2019): Sexual Homicide in France. International Journal of Offender Therapy and Comparative Criminology, 1-22. DOI: 10.1177/0306624X19834418

Karakasi, M. V. - Vasilikos, E. - Voultsos, P. et al. (2017): Sexual Homicide: Brief Review of the Literature and Case Report Involving Rape, Genital Mutilation and Human Arson. DOI: 10.1016/j.jflm.2016.12.005, https://bit.ly/2tPR8pu

Kenyeres B. (1925): A törvényszéki orvostan tankönyve. Budapest: Universitas Könyvkiadó Társaság

Legát T. (2012a): Rémtörténet Törökszentmiklóson I.: Halálkút, Magyar Narancs, 16, https://magyarnarancs.hu/lokal/halalkut-79665

Legát T. (2012b): Rémtörténet Törökszentmiklóson II.: „Piroskával mindég baj volt”. Magyar Narancs, 17, https://magyarnarancs.hu/lokal/piroskaval-mindeg-baj-volt-79789

Majnár (1968): Halálra ítélték a négyszeres kéjgyilkos Kovács Pétert. Szolnok Megyei Néplap, 1968. augusztus 10. XIX., 187. https://library.hungaricana.hu/hu/view/SzolnokMegyeiNeplap_1968_08/?pg=61\&layout $=\mathrm{S}$

Myers, W. C. - Chan, H. C. (O.) - Mariano, T. et al. (2017): Sexual Homicide by Older Male Offenders. Journal of Forensic Sciences, 62, 4, 940-946. DOI: 10.1111/1556-4029.13388, https:// www.ncbi.nlm.nih.gov/pmc/articles/PMC5505732/

NANE Egyesület - PATENT Egyesület (2012): Szakmai módszertani útmutató a párkapcsolati eröszak elleni hatékony fellépésre. Budapest: NANE Egyesület - PATENT Egyesület, http:// mek.oszk.hu/13900/13984/13984.pdf

U.S. Department of Justice - Federal Bureau of Investigation (1992): Ted Bundy Multiagency Inversigative Team Report 1992. https:/www.scribd.com/document/367611931/Ted-Bundy-Multiagency-Investigative-Team-Report-1992-From-Tedbundy-com

URL1: https://ec.europa.eu_ 